\title{
Marx e a Comuna de Paris
}

\author{
David Maciel ${ }^{*}$ \\ macieldavid@ig.com.br
}

Resumo: Desde 1871, o debate sobre a Comuna de Paris tem absorvido as mais diversas lideranças políticas, historiadores e cientistas sociais. Identificada como a primeira revolução especificamente proletária da História, a Comuna de Paris inspirou outros movimentos revolucionários e é considerada um marco na luta anticapitalista, a primeira manifestação histórica de ditadura do proletariado. Neste trabalho, pretendemos apresentar uma leitura alternativa da Comuna, com base nas formulações de Marx, para quem esta foi apenas um passo inicial em direção à ditadura do proletariado, sem, porém, constituir-se enquanto tal por ter sido abortada pela violência contrarrevolucionária, impedindo-a de levar a cabo a expropriação dos capitalistas pelos trabalhadores.

Palavras-Chave: Comuna de Paris, ditadura do proletariado, revolução social.

\section{INTRODUÇÃO}

O debate sobre a Comuna de Paris de 1871 tem, ao longo das décadas, envolvido não apenas historiadores e cientistas sociais, mas militantes e lideranças políticas das mais variadas posições. Para os marxistas, a Comuna de Paris é considerada um marco histórico na luta anticapitalista, o que foi ressaltado pelo próprio Marx ainda durante sua vigência, ao afirmar em carta a L. Kugelman que "porém, mesmo com tudo isso, esse levante de Paris - ainda que derrubado pelos lobos, porcos e cães abjetos da velha sociedade - é o ato mais glorioso de nosso partido desde a Insurreição de Junho em Paris" (MARX, 2011, p. 208).

Identificada como a primeira revolução especificamente proletária da História, a breve experiência da Comuna não só inspirou outros movimentos revolucionários, como a Revolução de Outubro, mas também foi associada

\footnotetext{
* Doutor em História pelo Programa de Pós-graduação em História da UFG e Professor de História Contemporânea da Faculdade de História da UFG.
} 
positivamente ao conceito de ditadura do proletariado, como sua primeira manifestação histórica. Tal leitura da Comuna no interior do marxismo (e que se tornou uma espécie de "senso comum") inicia-se com as breves formulações de Engels sobre o assunto, mas deve-se, sobretudo, à teorização de Lênin, apresentada no famoso "O Estado e a revolução" e em outros textos.

Neste trabalho, pretendemos apresentar uma leitura alternativa da Comuna, tomando por base as próprias expressões de Marx que, à primeira vista, parecem aproximar o caráter da Comuna de Paris ao conceito de ditadura do proletariado. Para Marx, entretanto, esta foi apenas um passo inicial nessa direção, sem constituir-se enquanto tal, por ter sido abortada pela violência contrarrevolucionária. A verdadeira inversão na relação entre Estado e sociedade promovida pela Comuna, seu caráter radicalmente democrático e seu conteúdo social proletário permitem sua caracterização como uma experiência de ditadura do proletariado - ou seja, como a forma política da transição do capitalismo ao comunismo, como por diversas vezes Marx definiu esse conceito -; no entanto, um fato incontornável é que Marx nunca chamou a Comuna de Paris por esse nome.

Aqui avançamos a hipótese de que Marx nunca conceituou a Comuna de Paris como ditadura do proletariado, porque ela pouco avançou no processo de expropriação do capital, de "socialização dos meios de produção", apesar da ruptura que realizou em relação ao Estado burguês e da novidade histórica que representou enquanto forma política do governo dos trabalhadores, enquanto radical socialização da política, abolindo a divisão entre governantes e governados.

\section{Os textos de Marx Sobre a Comuna}

As primeiras formulações de Marx a respeito do processo político que desembocou na Comuna de Paris foram a primeira e a segunda mensagem do Conselho Geral da Associação Internacional dos Trabalhadores (AIT) sobre a Guerra Franco-Prussiana.

Marx começa a primeira mensagem (MARX, 2011, p. 21-25), datada de 23 de julho de 1870, denunciando a perseguição promovida pelo governo de Luís Napoleão às seções francesas da AIT, por estas posicionarem-se contra o plebiscito convocado pelo governo no ano anterior como uma manobra para legitimá-lo e escamotear sua crise interna. Em seguida, condena a Guerra Franco-Prussiana, recém-iniciada, como uma guerra meramente dinástica uma guerra entre monarquias bonapartistas, não entre as nações francesa e alemã, cada qual interessada em fortalecer-se politicamente à custa de uma 
guerra "nacional" -, não sem antes denunciar as manobras entre Napoleão e Bismarck contra a Áustria (em 1866) e em favor da criação da Alemanha do Norte.

No caso francês, a guerra eclodiu como uma reedição do golpe de 1851, ao reunificar as classes proprietárias (com o apoio do campesinato) contra a classe operária. Classe operária esta que emergiu no final da década de 1860 como a principal força de contestação ao governo bonapartista, desencadeando inúmeras greves e radicalizando suas posições políticas em defesa do socialismo. Apesar disso, "seja qual for o resultado da guerra de Luís Bonaparte com a Prússia", vaticina Marx, "o dobre fúnebre do Segundo Império já soou em Paris" (MARx, 2011, p. 23). Do lado alemão, Marx acusa o governo de Bismarck de utilizar-se de uma guerra defensiva para unificar o país sob a Prússia e consolidar um regime que combinasse o velho sistema político prussiano com o seu "verdadeiro despotismo" e o "democratismo de fachada" (p. 23), copiados do Segundo Império francês, revivendo o bonapartismo do outro lado do Reno.

Diante dessa situação, a primeira mensagem reafirma a posição internacionalista da AIT e dos operários franceses e alemães contra a guerra dinástica e em defesa da união e da solidariedade proletárias; e, ainda, ao finalizar, alerta o proletariado alemão para os riscos de a guerra defensiva tornar-se ofensiva. Nessa situação, tanto a vitória como a derrota seriam uma desgraça para a causa proletária, pois colocariam a Alemanha aos pés da Rússia, principalmente no caso do apoio russo contra a França.

A segunda mensagem (MARX, 2001, p. 27-33) é datada de 9 de setembro de 1870, quando as tropas napoleônicas já haviam sido derrotadas em Sedan, Luís Napoleão estava preso e a República havia sido proclamada em Paris. Marx inicia seu documento lembrando o acerto do vaticínio da mensagem anterior de que a Guerra Franco-Prussiana levaria à queda o Segundo Império na França e de que poderia levar a Alemanha a abandonar a postura defensiva e desencadear uma ofensiva contra o povo francês. Logo em seguida, passa a contestar os argumentos do governo prussiano, da burguesia e dos nacionalistas alemães em favor do desmembramento da República francesa e da anexação de territórios franceses. Primeiramente, mostra a falácia de que o bombardeamento de Estrasburgo e a conquista da Alsácia e da Lorena garantiriam a segurança alemã contra um futuro ataque francês e de que, ao contrário dos franceses, os alemães agiam motivados por questões meramente defensivas e não anexacionistas.

Em segundo lugar, demonstra como a postura ofensiva da Alemanha tornou o czar da Rússia o árbitro da Europa, reforçando seu prestígio externo 
em um momento em que o czarismo russo começava a sofrer os primeiros abalos internos. Isso porque, de um lado, a oposição do czarismo russo à criação do Império Alemão obrigava-o a ser um instrumento da política czarista contrarrevolucionária na Europa para apaziguar a situação; de outro lado, o desmembramento da França a levaria a buscar uma aliança com a Rússia contra a Alemanha, criando a possibilidade de uma guerra das raças latina e eslava contra a raça germânica. De fato, essas duas previsões vieram a se realizar; tanto a política pró-russa adotada por Bismarck nos 20 anos seguintes, quanto a aliança franco-russa e a Primeira Guerra Mundial ocorridas posteriormente.

Em contraposição à postura beligerante dos governos, Marx ressalta a posição internacionalista do proletariado alemão, que defendia uma paz honrosa com a França, criticava a perspectiva de anexação da Alsácia e da Lorena e exigia o reconhecimento da República francesa. Em nome da AIT, Marx saúda o fim do Segundo Império e a proclamação da República na França, apesar de reconhecer seus limites, afirmando que "esta República não subverteu o trono, apenas tomou o seu lugar, que havia vacado. Ela foi proclamada não como uma conquista social, mas como uma medida nacional de defesa" (MARx, 2011, p. 32).

Composta pela burguesia republicana e pelos monarquistas orleanistas, que por sua vez controlavam os cargos decisivos, o governo republicano possuía o mesmo pavor da classe operária que o Segundo Império. No entanto, Marx afirma que, com os prussianos às portas de Paris, a tentativa de derrubada do novo governo pelo operariado seria uma "loucura desesperada” (p. 32), devendo a classe operária francesa aproveitar as liberdades republicanas para avançar em sua organização política, ao mesmo tempo em que deveria defender o país sem deixar-se iludir pelas recordações de 1792, ou seja, pela perspectiva jacobina de defesa nacional.

Nessa avaliação, Marx sugere que o enfrentamento aberto da classe operária contra o governo republicano - em uma situação em que os prussianos ainda ocupavam militarmente o país, como viria a ocorrer na Comuna de Paris - seria extremamente temerário, com riscos enormes para as condições de luta recém-conquistadas e de consequências imprevisíveis para a própria sorte da República, pois a restauração monárquica era uma possibilidade real. A importância dessa "casualidade" foi reafirmada por ele em uma carta enviada a L. Kugelman em 17 de abril de 1871, quase um mês após a proclamação da Comuna de Paris. Segundo Marx, "o 'acaso' desfavorável e decisivo não está, desta vez, nas condições gerais da sociedade 
francesa, mas na presença da Prússia na Alemanha e em sua posição próxima à Paris" (MArx, 2011, p. 209).

Uma vez mais, sua análise da situação mostrou-se acertada, como a evolução futura dos acontecimentos viria confirmar; o apoio prussiano à repressão desencadeada pelo governo republicano foi decisivo para a derrota da Comuna, com o massacre de milhares de trabalhadores e o desmantelamento do movimento operário francês por uma década.

No entanto, continua Marx:

[...] disso os parisienses sabiam muito bem. Mas também o sabiam os canalhas burgueses de Versalhes. Justamente por isso, colocaram aos parisienses a alternativa de ou aceitar a luta ou sucumbir sem lutar. A desmoralização da classe trabalhadora, no último caso, teria sido uma desgraça muito maior do que o ocaso de um número qualquer de "líderes". A luta da classe trabalhadora contra a classe dos capitalistas e seu Estado entrou, com a luta parisiense, em nova fase. Qualquer que seja o andar das coisas no futuro imediato, o certo é que se conquistou um novo ponto de partida de importância histórico-mundial. (MARX, 2011, p. 209)

Esse trecho mostra que - apesar de considerar a situação desfavorável para uma insurreição operária, tese confirmada pelos fatos - Marx também pondera que a passividade diante da ofensiva burguesa é ainda pior para o movimento operário que uma derrota momentânea, com o sacrifício de suas lideranças. Esse posicionamento se justifica pela leitura que Marx fazia da revolução de 4 de setembro de 1870 (que derrubou o Segundo Império) e do governo republicano que se lhe seguiu. Para ele, o Segundo Império foi a mais adequada forma política desenvolvida historicamente pela burguesia em favor de sua dominação sobre os trabalhadores. Em contrapartida, sua derrubada foi um feito histórico dos trabalhadores de Paris, jamais realizado. Esses não poderiam retroceder diante de um governo republicano só tornado possível pelo levante popular de 4 de setembro, mas que - em seu conteúdo de classe, em sua formatação institucional e em sua postura frente aos trabalhadores - era uma edição atualizada do bonapartismo do Segundo Império após a derrota de Sedan.

$\mathrm{Na}$ terceira mensagem do Conselho Geral da AIT, conforme consta no segundo rascunho de redação de A Guerra Civil na França, Marx afirma:

A revolução operária de Paris de 4 de setembro era o único título legal da Assembleia Nacional reunida em Bordeaux e de seu poder Executivo. Sem ela, a Assembleia Nacional teria sido obrigada a dar lugar imediata- 
mente ao Corps législatif eleito por sufrágio universal e dissolvido pelo braço da Revolução. [...] E Paris era agora pressionada, pelos gritos insultantes dos escravocratas rebelados de Bordeaux, ou a depor suas armas e reconhecer que sua revolução de 4 de setembro não tivera outro propósito do que o de transferir o poder de Luís Bonaparte e sua corja para seus rivais monárquicos, ou a seguir em frente como a campeã francesa do autossacrifício, que só pode ser salva de sua ruína e se regenerar por meio da superação revolucionária das condições políticas e sociais que haviam engendrado o Segundo Império e que, sob sua égide acolhedora, amadureceriam até a completa podridão. (MARX, 2011, p. 181)

Ou seja, diante da ameaça de restauração da forma mais desenvolvida do poder burguês, com a reversão das conquistas de 4 de setembro, o proletariado parisiense deveria lutar para superar a ordem social que sustentava o bonapartismo, mesmo que mediante intenso sacrifício e sob a ameaça da derrota. Diante disto, a luta de Paris adquiria um significado histórico-mundial, pois anunciava que a revolução social assumia um novo conteúdo histórico, alterando a dinâmica da luta de classes daí em diante, e não apenas na França.

Essa leitura contradiz aqueles que - a partir dos alertas e ressalvas levantados por Marx em relação às condições em que se instalou a Comuna e à sua própria experiência prática - insistem em acusá-lo de descompromisso ou mesmo de leviandade e oportunismo post festum ante essa experiência revolucionária. Isso, por conta de uma postura política pretensamente "estadolatra", dirigista (afinal os membros da AIT na Comuna eram minoria, e mesmo entre eles havia divergências com as orientações do Conselho Geral) e/ou contrária às experiências de autogestão. Não faltam ainda aqueles que separam o Marx crítico da economia política do Marx analista e ativista político, pretendendo "salvar" o primeiro em relação ao segundo e, assim, apelando ao economicismo para defender o legado crítico marxiano. Como se para Marx a tese fundante de sua propositura política - a emancipação dos trabalhadores só pode ser obra dos próprios trabalhadores - só devesse ser levada a sério no papel. O equívoco metodológico, para não dizer político, dessa operação é por si evidente, particularmente à luz do método proposto pelo próprio Marx. Em um aspecto ou em outro, a crítica de esquerda a Marx abandona a análise do contexto e abstrai a própria experiência histórica da Comuna, para limitar-se à denúncia de frases soltas e aos não ditos de Marx. Os críticos esquecem-se de que, afinal (e independente da opinião de Marx) a Comuna foi derrotada, cobrando um preço altíssimo do operariado francês 
e de seu movimento, justamente pelas causas apontadas pioneiramente pela análise marxiana.

Finalmente, Marx destaca a postura da classe operária inglesa, que exigiu do seu governo o reconhecimento da República francesa e a condenação do desmembramento da França pela Prússia. Seu objetivo era conclamar os operários de todos os países a agirem, a fim de se evitar que a Guerra Franco-Prussiana se transformasse no "prenúncio de conflitos internacionais ainda mais mortíferos" e que conduzisse "a um renovado triunfo sobre os operários pelos senhores da espada, da terra e do capital" (MARX, 2011, p. 33).

Entre a segunda mensagem do Conselho Geral da AIT, de setembro de 1870, e a terceira, de maio de 1871, denominada A Guerra Civil na França (MARx, 2001, p. 35-82) ocorreram as situações que Marx mais temia: a Alsácia e a Lorena foram anexadas pela Prússia, desmembrando o território francês; o Império Alemão foi proclamado sob a égide da Prússia e do bonapartismo bismarckiano; o acordo de paz entre o governo republicano e Bismarck foi baseado na hostilidade brutal à classe operária; e a guerra civil entre o operariado parisiense rebelado e o governo republicano eclodiu com os prussianos às portas de Paris.

Por proposta do próprio Marx, em 28 de março, o Conselho Geral encarregou-o de redigir uma declaração sobre os acontecimentos franceses; porém, após diversos adiamentos, alguns justificados pela própria indefinição da situação, ou por falta de informações, a mesma só veio à luz dois meses depois (MCLellan, 1990, p. 418-419). Nesse período, Marx redigiu dois rascunhos de redação, mais tarde intitulados materiais preparatórios para A Guerra Civil na França. O primeiro (MARx, 2011, p. 83-152) com quase o dobro de páginas da versão final e o segundo (p. 153-184) um pouco menor que aquele. No primeiro rascunho, Marx analisa detalhadamente a evolução dos acontecimentos, apresentando os documentos que utilizou em sua análise (informes jornalísticos, manifestos, decretos e medidas editados tanto pelo governo republicano e a assembleia legislativa quanto pela Comuna e a Guarda Nacional de Paris), ${ }^{1}$ conceituando tanto a Comuna quanto o governo republicano e seus respectivos vínculos sociais. O segundo rascunho é mais resumido, complementando o primeiro em termos de informações e sintetizando alguns pontos. Em ambos, Marx desenvolve algumas formulações teóricas que só aparecerão na versão definitiva de forma sintetizada ou parcial. No entanto, a leitura dos dois rascunhos é fundamental para se historiar o percurso reflexivo e teórico desenvolvido por Marx ao longo da experiência da Comuna e para a discussão que se propõe aqui. 
A terceira mensagem é uma síntese dos dois rascunhos de redação, privilegiando os dados e fatos mais importantes; apresenta de forma sucinta as elaborações teóricas anteriormente desenvolvidas e defende as posições da Comuna e da AIT diante da ofensiva contrarrevolucionária e da campanha de difamação veiculada pela imprensa.

Nesse sentido, podemos afirmar que - mais do que a falta de informações e a imprevisibilidade do seu desfecho - a gravidade da situação para a classe operária francesa talvez explique o fato de que Marx só tenha cumprido a tarefa de redigir a mensagem do Conselho Geral da AIT depois que a Comuna de Paris foi derrotada. Ele atribui a derrota muito mais à ferocidade da reação da burguesia francesa (com a cumplicidade do governo prussiano) e às vacilações dos communards do que às condições extremamente desfavoráveis para uma experiência daquele tipo. Não é surpreendente que ainda durante a vigência da Comuna, entre março e maio, Marx - em cartas escritas no período - tenha manifestado seu ceticismo quanto às suas chances de sucesso e, ao mesmo tempo, reconhecido seu heroísmo e iniciativa histórica (MCLellan, 1990, p. 418).

De fato, a terceira mensagem é, acima de tudo, um documento político, em que Marx defende a Comuna e a AIT de seus detratores e despeja todo o peso de sua força argumentativa em uma denúncia mordaz das ações da burguesia e dos governos francês e prussiano. Não à toa, nesse texto Marx conceitua a situação francesa como de guerra civil, muito mais do que a simples oposição de uma cidade contra o governo nacional.

O texto começa com uma catilinária demolidora contra o governo republicano e seus personagens e contra a "conspiração contrarrevolucionária" deste e da Assembleia Nacional com o governo prussiano para massacrar a Paris rebelada. Marx denuncia tanto o caráter reacionário e oportunista do governo francês - dirigido pelos republicanos e monarquistas e composto pelas mesmas frações burguesas que se uniram contra os operários em junho de 1848 e apoiaram e/ou aceitaram o golpe de Luís Bonaparte e a instalação do Segundo Império - quanto suas negociações espúrias com Bismarck, aceitando a mutilação do território francês e o pagamento de pesadas indenizações em troca da devolução das tropas aprisionadas, para que estas massacrassem Paris.

Na segunda parte, Marx narra o processo que deu origem à proclamação da Comuna de Paris em 18 de março, caracterizando-a como uma revolução, e relata seus desdobramentos posteriores: a permissão de que parte da Guarda Nacional abandonasse a cidade; a manifestação burguesa de 22 de março, dispersada à bala pela Guarda Nacional; a eleição para os delegados 
da Comuna; a segunda campanha do governo contra Paris; a inoperância do decreto da Comuna, ordenando represálias contra os agentes de Versalhes; e a intransigência repressiva das tropas governistas. Marx procura contraditar os argumentos dos detratores da Comuna, mostrando como o apelo à violência sempre partiu do governo de Versalhes e da Assembleia Nacional - em sua postura abertamente contrarrevolucionária e antipopular - e não da Comuna, apesar das promessas de retaliação raramente cumpridas.

$\mathrm{Na}$ terceira parte, encontra-se o núcleo da formulação de Marx sobre a novidade histórica representada pela Comuna e seu caráter fundamentalmente revolucionário. Nessa operação, Marx revela de forma explícita um dos elementos estruturantes de seu método científico, de acordo com o qual as categorias e conceitos devem emergir dos fenômenos concretos, historicamente constituídos e, portanto, diretamente determinados pelo movimento do real para possuírem eficácia explicativa. Marx conceitua a Comuna como a antítese do Segundo Império e da República na França, tanto enquanto regimes burgueses, quanto como expressão do apogeu do Estado burguês em sua aparelhagem institucional. Ou seja, a Comuna é a antítese do Segundo Império e da República, porque é o governo da classe operária, a classe contra quem esses regimes foram criados e se sustentaram, ao unificar as frações burguesas e classes proprietárias em torno desse imperativo político. A Comuna também é a forma positiva da República social anunciada em fevereiro de 1848 e abortada pelo bonapartismo francês.

O contraponto entre a Comuna e o Segundo Império é decisivo na caracterização que Marx faz da primeira, pois ela é o inverso deste, não apenas por conta de seu conteúdo social, como também por conta de sua própria formatação política. No primeiro rascunho de redação de $A$ Guerra Civil na França, Marx avança em seu conceito, afirmando que "ela é o povo agindo para si mesmo, por si mesmo" (MARx, 2011, p. 108), ou ainda que a Comuna é "a maior revolução deste século", quando o drama desta ainda se desenrolava (p. 125). Mais adiante, Marx desenvolve uma formulação não contida em toda sua inteireza no texto que veio a público logo depois do fim da Comuna. No primeiro rascunho ele diz:

Foi, portanto, uma revolução não contra essa ou aquela forma do poder estatal, seja ela legítima, constitucional, republicana ou imperial. Foi uma revolução contra o Estado mesmo, este aborto sobrenatural da sociedade, uma reassunção, pelo povo e para o povo, de sua própria vida social. Não foi uma revolução feita para transferi-lo de uma fração das classes dominantes para outra, mas para destruir essa horrenda maquinaria da dominação de classe ela mesma. Não foi uma dessas lutas insignificantes 
entre as frações executiva e parlamentar da dominação de classe, mas uma revolta contra ambas essas formas, integrando uma à outra, e da qual a forma parlamentar era apenas um apêndice defeituoso do Executivo. $\mathrm{O}$ Segundo Império foi a forma fina dessa usurpação estatal. A Comuna foi sua direta negação e, assim, o início da Revolução Social do século XIX. (MarX, 2011, p. 127)

Além disso, como governo da classe operária, a Comuna não só inverteu o conteúdo social do Estado, como inverteu sua relação com a sociedade; daí a fórmula de que a Comuna "foi uma revolução contra o Estado" ou de que é "o início da Revolução Social do século XIX", não mera revolução política na qual uma nova classe dominante assume o poder para aperfeiçoar o Estado de acordo com seus interesses. Nesse ponto, Marx faz uma digressão sobre a evolução do Estado francês, mostrando como o Segundo Império bonapartista consumou as tendências centralistas e parasitárias, iniciadas ainda durante a formação da monarquia absolutista francesa. Segundo ele:

O poder estatal centralizado, com seus órgãos onipresentes, com seu exército, polícia, burocracia, clero e magistratura permanentes - órgãos traçados segundo um plano de divisão sistemática e hierárquica do trabalho -, tem sua origem nos tempos da monarquia absoluta e serviu à nascente sociedade da classe média como uma arma poderosa em sua luta contra o feudalismo. Seu desenvolvimento, no entanto, permaneceu obstruído por todo tipo de restos medievais, por direitos senhoriais, privilégios locais, monopólios municipais e corporativos e códigos provinciais. A enorme vassoura da Revolução Francesa do século XVIII varreu todas essas relíquias de tempos passados, assim limpando ao mesmo tempo o solo social dos últimos estorvos que se erguiam ante a superestrutura do edifício do Estado moderno erigido sob o Primeiro Império, ele mesmo o fruto das guerras de coalizão da velha Europa semifeudal contra a França moderna. Durante os regimes subsequentes, o governo, colocado sob controle parlamentar - isto é, sob o controle direto das classes proprietárias -, tornou-se não só uma incubadora de enormes dívidas nacionais e de impostos escorchantes, como também, graças à irresistível fascinação que causava por seus cargos, pilhagens e patronagens, converteu-se no pomo da discórdia entre as facções rivais e os aventureiros das classes dominantes; mas o seu caráter político mudou juntamente com as mudanças econômicas ocorridas na sociedade. No mesmo passo em que o progresso da moderna indústria desenvolvia, ampliava e intensificava o antagonismo de classe entre o capital e o trabalho, o poder do Estado foi assumindo cada vez 
mais o caráter de poder nacional do capital sobre o trabalho, de uma força pública organizada para a escravização social, de uma máquina de despotismo de classe. [...] O Império, tendo o coup détat por certidão de nascimento, o sufrágio universal por sanção e a espada por cetro, professava apoiar-se nos camponeses, ampla massa de produtores não diretamente envolvida na luta entre capital e trabalho. Professava salvar a classe operária destruindo o parlamentarismo e, com ele, a indisfarçada subserviência do governo às classes proprietárias. Professava salvar as classes proprietárias sustentando sua supremacia econômica sobre a classe operária; e, finalmente, professava unir todas as classes reavivando para todos a quimera da glória nacional. Na realidade, ela era a única forma de governo possível num tempo em que a burguesia já havia perdido e a classe operária ainda não havia adquirido a capacidade de governar a nação. O Império foi aclamado por todo o mundo como o salvador da sociedade. Sob sua égide, a sociedade burguesa, liberta de preocupações políticas, atingiu um desenvolvimento inesperado, até para ela mesma. [...] O poder estatal, que aparentemente pairava acima da sociedade, era, na verdade, o seu maior escândalo e a incubadora de todas as suas corrupções. [...] O imperialismo (entendido aqui como forma política do Segundo Império francês - D. M.) é a forma mais prostituída e, ao mesmo tempo, a forma acabada do poder de Estado que a sociedade burguesa nascente havia começado a criar como meio da sua própria emancipação do feudalismo, e que a sociedade burguesa madura acabou transformando em meio para a escravização do trabalho pelo capital. A antítese direta do Império era a Comuna. (MARx, 2011, p. 54-56)

A longa citação se justifica pelo fato de que aqui Marx não só analisa sinteticamente a formação e evolução histórica da maquinaria estatal francesa e a relaciona dialeticamente ao desenvolvimento do capitalismo francês e ao processo de divisão social do trabalho, mas também evidencia sua perspectiva metodológica, ao compreender esse processo de modo totalizante. Isso porque (como esse trecho claramente indica em sua leitura) o desenvolvimento de um poder político baseado na centralização nacional, na hierarquia e na divisão do trabalho no interior do corpo burocrático ocorria "juntamente" - "no mesmo passo", não antes, nem depois - ao desenvolvimento das modernas relações de produção, influenciando-se mutuamente e de modo dialético. O que, por sua vez, também não implica em descartar a importância dos processos de ruptura revolucionária, como a Revolução Francesa, em favor de uma visão "gradualista” da História. Os espíritos pós-modernos ou afins, acostumados a atribuir a Marx uma visão determinista e economicista do processo histórico, devem se assombrar com 
essa síntese (se é que a leram alguma vez) que joga por terra suas críticas ligeiras ou mal-intencionadas.

Além disso, Marx compara o regime do Segundo Império com os regimes anteriores e o qualifica como a forma política mais evoluída e, ao mesmo tempo, mais prostituída, desenvolvida pela burguesia para a "escravização" do trabalho, pois baseada no total parasitismo da burocracia diante da sociedade real. Portanto, os trabalhadores de Paris não estavam diante de qualquer forma de dominação do capital sobre o trabalho, mas diante do bonapartismo, a forma política que levou o despotismo de classe do capital ao auge em sua aparente separação entre economia e política, ou entre sociedade civil e Estado. Uma forma política com características universais, capaz de se reproduzir em outros países, principalmente na Europa - como já vinha ocorrendo na Alemanha e na Itália de modo particular - por ser a mais adequada à dominação burguesa na era do conflito aberto entre capital e trabalho. $\mathrm{Ou}$, em suas próprias palavras, na era marcada pelo "início da Revolução Social", quando diante do horizonte histórico burguês só restava, como alternativa, a perspectiva socialista dos trabalhadores. Assim afirma Marx no segundo rascunho de redação para A Guerra Civil na França:

A usurpadora ditadura do corpo governamental sobre a própria sociedade, que à primeira vista dá a impressão de elevar-se por sobre todas as classes e humilhá-las, tornou-se, na verdade, ao menos no Continente Europeu, a única forma possível de Estado em que a classe apropriadora pode continuar a dominar a classe produtora. (MARx, 2011, p. 169)

Ou ainda, mais adiante no mesmo texto:

O Império não é, como seus predecessores - a Monarquia legítima, a Monarquia constitucional e a República parlamentar -, [apenas] uma das formas políticas da sociedade burguesa; ela é, ao mesmo tempo, sua forma mais prostituída, mais completa e acabada. O Império é o poder estatal do domínio moderno de classe, ao menos no Continente Europeu. (p. 184)

Ao contrário disto, com sua experiência prática, a Comuna inscreveu de modo definitivo a perspectiva histórica dos trabalhadores como uma possibilidade concreta, não mais como uma simples previsão teórica, posta pela própria dinâmica reprodutiva da sociedade capitalista. Ou, conforme ressalta Marx, a primeira revolução social em que os revolucionários não se limitam a tomar para si a maquinaria do Estado que encontram, aperfeiçoando-a e colocando-a ao seu serviço, mas a quebram em função do seu próprio interesse. 
Em relação a isso, Marx assevera na terceira mensagem: a Comuna...

era essencialmente um governo da classe operária, o produto da luta da classe produtora contra a classe apropriadora, a forma política enfim descoberta para se levar a efeito a emancipação econômica do trabalho. [...] A Comuna, portanto, devia servir como alavanca para desarraigar o fundamento econômico sobre o qual descansa a existência das classes e, por conseguinte, a dominação de classe. Com o trabalho emancipado, todo homem se converte em trabalhador e o trabalho produtivo deixa de ser um atributo de classe. [...] Ela visava à expropriação dos expropriadores. Queria fazer da propriedade individual uma verdade, transformando os meios de produção, a terra e o capital, hoje essencialmente meios de escravização e exploração do trabalho, em simples instrumentos de trabalho livre e associado. (MARx, 2011, p. 59-60)

Esse "autogoverno dos produtores", segundo Marx, não apenas expressa uma mudança revolucionária no caráter de classe do poder político, "a maior revolução deste século" (p. 125), mas também quebra o moderno poder de Estado ao expropriá-lo das classes dominantes e inverter sua formatação institucional. Conforme alega Marx no primeiro rascunho de redação:

Que a revolução é feita em nome e assumidamente para as massas populares, isto é, para as massas produtoras, isto é uma característica que esta revolução tem em comum com todas as outras. O novo elemento é que o povo, após o primeiro levante, não desarmou a si mesmo e entregou seu poder nas mãos dos velhacos republicanos das classes dominantes; ao constituir a Comuna, tomaram o comando de sua revolução em suas próprias mãos e ao mesmo tempo encontraram, em caso de sucesso, os meios para mantê-lo nas mãos do próprio povo, substituindo a maquinaria estatal, a maquinaria governamental das classes dominantes, por uma maquinaria estatal própria. (MARX, 2011, p. 138)

A "revolução contra o Estado" representada pela Comuna abole a maquinaria estatal tal como ela existia, como uma máquina da minoria para a exploração da maioria em nome do conjunto de ambas - ou seja, do Povo-Nação - e cria uma maquinaria estatal nova, inédita. Nessa, o poder político não desaparece, e nem a política, mas ganha novo conteúdo e nova forma, pois fundado no governo da maioria, no governo dos produtores, que o exercem diretamente, sem separar-se de suas funções produtivas, sem autonomizar uma camada de burocratas e representantes políticos que 
passaria a sobreviver à custa do produto social gerado pelos trabalhadores. Como se sabe, poucos anos depois, em 1874-75 - nos comentários críticos redigidos em relação ao livro Estatismo e anarquia de Bakunin - Marx reafirma esta tese acerca da necessidade de criação de uma maquinaria estatal nova para viabilizar e mesmo "acelerar" a emancipação do trabalho (MARX, 2003, p. 149-150).

No segundo rascunho Marx vai além, identificando a Comuna como forma própria de autogoverno, independentemente de seu conteúdo de classe, pois mesmo nas cidades e regiões em que predominam a pequena burguesia e o campesinato no seio das camadas populares, o governo comunal é o autogoverno dessas classes, alavanca de sua emancipação diante das classes dominantes. Ou seja, a ruptura realizada pela Comuna em relação ao aparato estatal é tão absoluta que a simples quebra da maquinaria estatal permite às classes populares exercerem o poder diretamente, sem a intermediação da burocracia e de seus representantes políticos, como se deduz da seguinte passagem:

Em sua mais simples concepção, a Comuna visava à destruição preliminar da velha maquinaria governamental em suas sedes centrais - Paris e as outras grandes cidades da França - e sua substituição por um verdadeiro autogoverno que, em Paris e nas grandes cidades, bastiões da classe trabalhadora, era o governo da classe trabalhadora. (MARx, 2011, p. 172)

Por isso, a instalação da forma política comunal, conforme foi desenvolvida em Paris, também era do interesse da pequena burguesia e do campesinato, não só do proletariado, conforme Marx assinala na terceira mensagem, avaliando as medidas tomadas pela Comuna. No primeiro rascunho, Marx ressalta como a experiência da Comuna dividiu a sociedade francesa entre as classes beneficiárias da máquina estatal bonapartista e as classes submetidas à sua opressão. Segundo ele:

Todos os elementos vitais da França reconhecem que uma república só é possível na França e na Europa como uma "República social", isto é, uma república que desapropria o capital e a classe dos proprietários rurais da máquina estatal para que esta seja assumida pela Comuna, que declara francamente que a "emancipação social" é o grande objetivo da República e, assim, garante essa transformação social pela organização comunal. (MARx, 2011, p. 137)

Daí a importância histórico-mundial da experiência da Comuna que - por conta de sua condição de "revolução contra o Estado" e por ter 
descoberto a forma política da emancipação do trabalho - adquiria um caráter universal, pois inscrito como possibilidade em todas as sociedades marcadas pela contradição entre capital e trabalho. Por isso, na avaliação de Marx, "a Comuna de Paris pode cair, mas a Revolução Social que ela iniciou triunfará. Seu local de nascimento é em toda parte” (p. 176).

Entre as medidas da Comuna adotadas nessa perspectiva, Marx destaca: a supressão do Exército permanente e da polícia e sua substituição pelo povo armado na Guarda Nacional; a instalação do sufrágio universal a serviço do povo (não como mero mecanismo de sanção do poder burguês, como no Segundo Império) com a consequente eleição dos delegados da Comuna por sufrágio universal para mandatos responsáveis e revogáveis em qualquer tempo - medida esta válida para todos os cargos públicos, inclusive juízes e magistrados; o fim dos privilégios burocráticos, com a remuneração dos servidores públicos equivalente ao salário de um operário; a separação entre Igreja e Estado, com a laicização e a democratização do ensino público. O sufrágio universal, a responsabilidade e a revogabilidade dos mandatos são os mecanismos que garantem que na nova maquinaria estatal o poder seja exercido diretamente pelos trabalhadores e que impedem a formação de uma nova camada burocrática autônoma.

O alcance do sufrágio universal - agora um verdadeiro instrumento de poder popular, não mais instrumento do "democratismo de fachada" que esconde o "despotismo verdadeiro" de classe - e da quebra da burocracia são ressaltados por Marx no primeiro rascunho, quando assinala sua importância para o poder político de novo tipo surgido com a Comuna. Segundo ele:

O sufrágio universal, que fora até então abusado - seja servindo para a sanção parlamentar do Sagrado Poder Estatal, seja como um joguete nas mãos das classes dominantes, tendo sido exercido pelo povo apenas uma vez em muitos anos a fim de sancionar o (para escolher os instrumentos do) domínio parlamentar de classe -, (é) adaptado aos seus propósitos reais: escolher, mediante as Comunas, seus próprios funcionários para a administração e legislação. Cai a ilusão de que a administração e o governo político seriam mistérios, funções transcendentes a serem confiadas apenas a uma casta de iniciados - parasitas estatais, sicofantas ricamente remunerados e sinecuristas ocupando altos postos, absorvendo a inteligência das massas e voltando-as contra si mesmas nos estratos mais baixos da hierarquia. Elimina-se a hierarquia estatal de cima a baixo e substituem-se os arrogantes senhores do povo por servidores sempre removíveis, uma responsabilidade de mentira por uma responsabilidade real, uma vez que eles passam a agir continuamente sob supervisão pública. 
[...] Toda a fraude dos mistérios e pretensões do Estado foi eliminada por uma Comuna que consistia em sua maior parte de simples trabalhadores organizando a defesa de Paris, fazendo a guerra contra os pretorianos de Bonaparte, assegurando o approvisionnement dessa imensa cidade, preenchendo todos os postos até então divididos entre governo, polícia e prefeitura, executando seu trabalho publicamente, de maneira simples, sob as circunstâncias mais difíceis e complicadas, e o fazendo, tal como o Milton no seu Paraíso perdido, por umas poucas libras, agindo à luz do dia, sem nenhuma pretensão à infalibilidade, sem se esconder atrás de balcões de procrastinação, sem escrúpulos de confessar seus erros no ato de corrigi-los. Fazendo das funções públicas - militares, administrativas, políticas - funções de trabalhadores reais, em vez de atributos ocultos de uma casta treinada (mantendo a ordem na turbulência da guerra civil, implementando medidas de recuperação geral). Quaisquer que sejam os méritos das medidas singulares da Comuna, sua mais formidável medida foi sua própria organização, improvisada no momento em que em uma porta estava o inimigo estrangeiro e em outra o inimigo de classe, provando com sua vida sua vitalidade, confirmando sua teoria com sua ação. (MARX, 2011, p. 129-130)

Além dessas medidas, Marx vislumbra a propagação do regime comunal para o resto do país, por conta de sua afinidade com os interesses pequeno-burgueses e camponeses, combatendo a argumentação de que isso significaria o fim da unidade nacional francesa. Ao contrário, nas cidades e distritos rurais seriam eleitos delegados para as assembleias locais e regionais e para a Assembleia Nacional reunida em Paris, com base no sufrágio universal e nos mesmos princípios de responsabilidade e revogabilidade dos mandatos. Ao invés de dispersar em uma federação de pequenos Estados, a unidade nacional, "o regime comunal teria restaurado ao corpo social todas as forças até então absorvidas pelo parasita estatal, que se alimenta da sociedade e obstrui seu livre desenvolvimento" (MARX, 2011, p. 59); teria ainda realizado a promessa não cumprida das revoluções burguesas, um governo barato, pois teria destruído o Exército permanente e o funcionalismo de Estado, suas duas maiores fontes de despesa. Por isso a Comuna não era uma tentativa anacrônica de reeditar os governos comunais das cidades medievais, mas, sim, uma forma política historicamente nova, resultante das relações sociais vigentes. De fato, naquele período, regimes comunais foram proclamados em Lyon, Marselha, Creusot, Toulouse e Narbonne, além de outras tentativas infrutíferas e de manifestações de apoio à Comuna de Paris em diversas localidades, indicando que a revolução se espraiava pelo país. 
Marx ressalta ainda a capacidade de direção política assumida pelo proletariado parisiense durante a revolução - em relação às demais camadas populares e em relação ao proletariado de outros países - pelo fato de a Comuna ser "governo operário e paladino audaz da emancipação do trabalho" (MARX, 2011, p. 63) e, ao mesmo tempo, antagônica à burguesia francesa e seu Estado. Além de afirmar o internacionalismo proletário, abrindo-se à participação protagônica de estrangeiros (como Frankel, Dombrowski e Wróblewski), a Comuna de Paris atraiu o apoio da pequena burguesia, com medidas como a moratória do pagamento das dívidas e a suspensão dos juros, colocando-se claramente em defesa dos interesses do campesinato. Em relação a este, a Comuna erigiu-se como sua aliada para que se emancipasse da ilusão bonapartista, das hipotecas cobradas pela burguesia, do grande proprietário rural e da variada fauna de parasitas que viviam do seu suor. O cerco a Paris - imposto pelo governo de Versalhes e pelas tropas prussianas - impediu que a aliança com o campesinato se concretizasse e esparramasse o regime da Comuna pelo país todo. Nesse ponto, Marx se refere à capacidade de hegemonia demonstrada pelo proletariado parisiense durante a existência da Comuna, cassando à burguesia o apoio de sua base de massa e solidificando uma ampla aliança popular em favor do novo regime e das transformações que se anunciavam.

De fato, a Comuna adotou medidas de "proteção social", como a proibição do trabalho noturno para os padeiros e a abolição das multas impostas arbitrariamente pelos patrões aos trabalhadores, e medidas de caráter claramente socializante, como entrega das oficinas e fábricas abandonadas ou fechadas para as associações operárias, porém, sob "reserva de compensação", ressalta Marx. Esta última medida mostra que a Comuna "visava à expropriação dos expropriadores" (conforme as palavras de Marx), porém não houve tempo para ir além disso. A partir das demandas dos próprios operários, a Comissão do Trabalho e das Trocas criou as "bolsas do trabalho", para receber e encaminhar os pedidos e as ofertas de emprego, e fortaleceu as cooperativas de produção controladas pelas associações operárias, encomendando-lhes os produtos de que a Comuna necessitava, viabilizando sua existência. Porém, os projetos da Comissão do Trabalho e das Trocas para a expropriação de todas as grandes fábricas não chegaram a se efetivar, e mesmo o decreto de entrega ao controle operário das fábricas abandonadas ou fechadas foi minimamente aplicado, pois apenas uma fábrica chegou a funcionar nas novas condições (RougerIE, 2001, p. 143-145).

Apesar da positividade atribuída à Comuna - ressaltada não só na terceira mensagem mas também nas cartas enviadas por ele naquele período ${ }^{2}-$ 
Marx não deixa de pontuar, ao longo do texto, o que considerava serem seus erros e vacilações. Nesse aspecto, os equívocos atribuídos à Comuna por Marx se devem fundamentalmente à timidez e à "benevolência" de determinadas atitudes tomadas em situações que exigiam maior radicalidade, por tratarse de uma guerra civil, como a permissão de que seus adversários fugissem para Versalhes e o não ataque sistemático à mesma Versalhes. Em carta a L. Kugelman, datada de 12 de abril de 1871, Marx já havia feito essa última crítica e ainda considerou que "o Comitê Central (da Guarda Nacional) renunciou ao seu poder cedo demais para dar lugar à Comuna. Novamente por causa de uma 'nobilitante' escrupulosidade!" (MARX, 2011, p. 208). Em nossa avaliação, Marx considerava prematura a transferência de poder do Comitê Central da Guarda Nacional para a Comuna não por qualquer perspectiva política centralista e antidemocrática, mas por conta da própria situação de emergência militar em que Paris se encontrava, a exigir uma ação militar coordenada, rápida e isenta de ambiguidades ou duplo comando. De fato, na fase final da Guerra Civil, surgiu um conflito de autoridade entre o Comitê Central da Guarda Nacional, o Conselho Militar da Comuna e o Comitê de Salvação Pública no tocante à coordenação das atividades de defesa, o que favoreceu a dispersão de iniciativas e o improviso, contribuindo decisivamente para o sucesso da invasão da cidade pelas tropas do governo republicano. ${ }^{3}$ Dez anos depois, em carta a F. D. Nieuwenhuis, fazendo um balanço da Comuna Marx diria que:

além de ter sido a rebelião de uma cidade em circunstâncias excepcionais, a maioria da Comuna não era de forma alguma socialista, nem poderia ser. Com um mínimo de bom senso, ela poderia obter de Versalhes um compromisso favorável a toda a massa do povo, o que era, afinal, a única coisa possível. (Apud Texier, 2005, p. 189)

Marx conclui seu trabalho, relatando as manobras pretensamente conciliadoras de Thiers em relação à Comuna. Para ganhar tempo, enquanto mantinha sua política de repressão dura, acertava com Bismarck um acordo de paz, no qual a França aceitava a mutilação de seu território e o pagamento de pesadas indenizações, em troca da devolução das tropas imperiais (aprisionadas pelos prussianos) para desencadear o ataque final sobre Paris. A ocasião tornou-se propícia para Bismarck elevar-se à condição de árbitro da política interna francesa, depois que o governo de Thiers perdeu as eleições municipais no final de abril, e ele aceitou o ditado prussiano como último recurso para derrotar a revolução. Por sua vez, a política de 
Bismarck é violentamente condenada por Marx, que acusa a Prússia de desempenhar o papel de um "assassino a soldo" em nome da solidariedade de classe da burguesia de todos os países contra toda e qualquer perspectiva revolucionária do proletariado. Segundo ele:

que na mais tremenda guerra do mundo moderno o exército conquistador e o exército conquistado confraternizem no massacre comum do proletariado, esse evento sem paralelo na história não representa, como pensa Bismarck, a repressão final de uma nova sociedade que avança, mas a redução a cinzas da sociedade burguesa. A empresa mais heroica de que ela ainda é capaz é a guerra nacional, a qual se evidenciou agora como pura fraude dos governos, engendrada para retardar a luta de classes e a ser descartada toda vez que essa luta de classes desemboque em guerra civil. A dominação de classe já não é capaz de se disfarçar sob um uniforme nacional; os governos nacionais são um só contra o proletariado. (MARX, 2011, p. 77-78)

\section{Comuna de Paris e ditadura do proletariado}

A verdadeira inversão na relação entre Estado e sociedade promovida pela Comuna, seu caráter radicalmente democrático e seu conteúdo social proletário sugerem sua caracterização como uma experiência de ditadura do proletariado, ou seja, como a forma política da transição do capitalismo ao comunismo, como por diversas vezes Marx definiu esse conceito.

Apesar de afirmar em A Guerra Civil na França que a Comuna de Paris era "a forma política enfim descoberta para se levar a efeito a emancipação econômica do trabalho" (MARx, 2011, p. 59), o autor não deu o passo para caracterizá-la como ditadura do proletariado, como à primeira vista suas formulações sobre esse conceito possam sugerir. De fato, nas outras afirmações em que a define de forma mais incisiva, predomina um tom condicionante que revela mais as suas potencialidades e pretensões do que suas realizações concretas. É o que ocorre quando ele declara que ela "deveria servir como uma alavanca para desarraigar o fundamento econômico sobre o qual descansa a existência das classes e, por conseguinte, da dominação de classe", ou alega que "ela visava (negritos nossos - D. M.) a expropriação dos expropriadores" (MARX, 2011, p. 59-60).

No primeiro rascunho, Marx desenvolve teoricamente as possibilidades históricas abertas com a instalação da Comuna, sendo ainda mais contundente na sua caracterização como experiência que "inaugura" a emancipação do trabalho, como "meio racional" para que o processo da luta de classes 
promova a abolição das classes de modo "humano" e "pacífico", favorecendo uma nova organização da produção. Em uma longa passagem, afirma ele inicialmente:

Tal é a Comuna - forma política da emancipação social, da libertação do trabalho da usurpação dos monopolistas dos meios de trabalho, sejam estes meios criados pelos próprios trabalhadores ou dados pela natureza. Assim como a máquina e o parlamentarismo estatal não são a vida real das classes dominantes, mas apenas os órgãos gerais organizados para sua dominação - as garantias, formas e expressões políticas da velha ordem das coisas -, assim também a Comuna não consiste no movimento social da classe trabalhadora e, portanto, no movimento de uma regeneração geral do gênero humano, mas sim nos meios organizados de ação. A Comuna não elimina a luta de classes, através da qual as classes trabalhadoras realizam a abolição de todas as classes e, portanto, de toda [dominação de] classe (porque ela não representa um interesse particular, mas a liberação do 'trabalho', isto é, a condição fundamental e natural da vida individual e social que apenas mediante usurpação, fraude e controles artificiais pode ser exercida por poucos sobre a maioria), mas ela fornece o meio racional em que essa luta de classe pode percorrer suas diferentes fases da maneira mais racional e humana possível. (MARx, 2011, p. 131)

Nas condições do governo comunal, a luta de classes não desaparece de imediato, pois a resistência contrarrevolucionária continua a existir e o movimento de emancipação do trabalho apenas teve início, mas cada novo intento das antigas classes dominantes acelera o processo de abolição das classes. Com a instalação da Comuna, o curso de emancipação dos trabalhadores já se inicia, simplesmente ao livrá-los dos pesados custos de manutenção da maquinaria estatal, sustentada pela mais-valia social arrancada de seu trabalho. A "reforma econômica" originada dessa "transformação política" (que, obviamente, demanda a expropriação econômica do capital para se efetivar) é parte do processo de supressão da exploração exercida pela burguesia e seus funcionários sobre os trabalhadores. Aqui a distinção conceitual (adotada por Marx) entre reforma e revolução tem um significado fundamental em nossa interpretação.

Dando sequência à sua formulação, Marx afirma:

Ela pode provocar violentas reações e revoluções igualmente violentas. Ela inaugura a emancipação do trabalho - seu grande objetivo -, por um lado ao remover a obra improdutiva e danosa dos parasitas estatais, cortando a fonte que sacrifica a imensa porção da produção nacional para 
alimentar o monstro estatal, e, por outro lado, ao realizar o verdadeiro trabalho de administração, local e nacional, por salários de operários. Ela dá início, portanto, a uma imensa economia, a uma reforma econômica, assim como a uma transformação política. A organização comunal, uma vez firmemente estabelecida em escala nacional, as catástrofes que sobre ela ainda poderiam se abater seriam esporádicas insurreições de escravocratas, as quais, mesmo que interrompendo por um momento o trabalho do progresso pacífico, apenas acelerariam o movimento ao pôr a espada nas mãos da Revolução Social. (MARx, 2011, p. 131)

Finalmente, a Comuna dá início ao processo de transição em direção à economia do "trabalho livre e associado", levando a luta de classes a um novo patamar.

As classes trabalhadoras sabem que têm de passar por diferentes fases da luta de classe. Sabem que a substituição das condições econômicas da escravidão do trabalho pelas condições do trabalho livre e associado só pode ser o trabalho progressivo do tempo (essa transformação econômica), que isso requer não apenas uma mudança na distribuição, mas uma nova organização da produção - ou, antes, requer a liberação (desobstrução) das formas sociais de produção no atual trabalho organizado (engendrado pela indústria atual), libertando-as dos grilhões da escravidão, de seu atual caráter de classe - e o estabelecimento de sua harmoniosa coordenação nacional e internacional. Elas sabem que essa obra de regeneração será continuamente atrasada e impedida pela resistência de direitos adquiridos e egoísmos de classe. Elas sabem que a atual "ação espontânea das leis naturais do capital e da propriedade fundiária" só pode dar lugar à "ação espontânea das leis da economia social do trabalho livre e associado" mediante um longo processo de desenvolvimento de novas condições, tal como ocorreu com a "ação espontânea das leis econômicas da escravidão" e com a "ação espontânea das leis econômicas da servidão". Mas elas sabem, ao mesmo tempo, que grandes passos podem ser dados desde já pela forma comunal de organização política e que é chegada a hora de iniciar esse movimento para elas mesmas e para o gênero humano. (MARX, 2011, p. 131-132)

O fato de a terceira mensagem ser um manifesto da AIT, não um texto de autoria pessoal (o que poderia ter constrangido Marx a avançar um conceito que não era consensual em seu interior) não explica esta lacuna. Nem no primeiro e segundo rascunhos - e mesmo depois, quando em 1872 assumiu a autoria do texto e o publicou juntamente com a primeira e a segunda mensagens sob o título de A Guerra Civil na França - ou em 
outros trabalhos, devidamente assinados, Marx não se manifestou de forma diferente. Por exemplo, pouco mais de um ano depois (no prefácio à edição alemã de 1872 do Manifesto do Partido Comunista), ele e Engels reconhecem que o desenvolvimento da grande indústria, a Revolução de Fevereiro de 1848 e, principalmente, a Comuna de Paris tornaram antiquados alguns aspectos do programa do "Manifesto", por evidenciar historicamente que a classe operária não pode simplesmente se apossar da maquinaria do Estado burguês, mas tem que quebrá-la; porém, a conceituação da Comuna como ditadura do proletariado não é efetuada. Citando uma frase de A Guerra Civil na França, afirmam eles: "a Comuna, nomeadamente, forneceu a prova de que 'a classe operária não pode limitar-se a tomar conta da máquina do Estado que encontra montada e pô-la em movimento para atingir os seus fins próprios"' (Marx \& Engels, 1982a, p. 96). Nada mais é dito quanto a isso.

Engels só vai defini-la como ditadura do proletariado vinte anos depois, ainda que brevemente, na introdução à edição de 1891 de A Guerra Civil na França, a partir justamente da constatação de que a Comuna iniciou a quebra da maquinaria estatal burguesa. Endereçada ao "filisteu alemão", segundo expressão dele mesmo, a definição da Comuna como ditadura do proletariado se insere em um conjunto de iniciativas tomadas por Engels em 1891, para combater a influência do reformismo e da "estadolatria" lassaleanos no Partido Social-Democrata Alemão, que tinha em curso a reformulação do seu programa (ENGELs, 2011, p. 187-197).

Recorrendo à autoridade teórica e política de Marx e dele mesmo nessa batalha, Engels reedita A Guerra Civil na França de Marx, com a introdução acima indicada. Também publica a Crítica ao Programa de Gotha - realizada por Marx em 1875 e endereçada em caráter confidencial à direção do partido -, texto em que este retoma explicitamente o conceito de ditadura do proletariado e critica a direção social-democrata por não incorporá-lo ao programa partidário em favor de uma visão "estadolatra" da luta política.

Nesse texto Marx afirma:

entre a sociedade capitalista e a sociedade comunista medeia o período de transformação revolucionária da primeira na segunda. A este período corresponde também o período político de transição, cujo Estado não pode ser outro senão a ditadura do proletariado. (MARX, s.d., p. 221)

Essa elaboração é uma versão sintética da fórmula desenvolvida vinte e cinco anos antes, em As lutas de classe em França de 1848 a 1850, quando 
Marx definiu o conceito de ditadura do proletariado pela primeira vez e da forma mais acabada desde então. Segundo ele:

a ditadura de classe do proletariado como ponto de trânsito necessário para a abolição das diferenças de classe em geral, para a abolição de todas as relações de produção em que aquelas se apoiam, para a abolição de todas as relações sociais que correspondem a essas relações de produção, para a revolução de todas as ideias que decorrem destas relações sociais. (MARX, 1982, p. 291)

No Manifesto do Partido Comunista, Marx já havia iniciado sua elaboração sobre o caráter da revolução proletária e do domínio político do proletariado, que se desdobraria dois anos depois no conceito de ditadura do proletariado:

o primeiro passo na revolução proletária é a passagem do proletariado à classe dominante, à conquista da democracia na luta. $\mathrm{O}$ proletariado usará o seu domínio político para ir arrancando todo o capital das mãos da burguesia... (MARX \& ENGELS, 1982a, p. 124)

Se associarmos essa formulação ao conceito de ditadura do proletariado anteriormente exposto, fica evidente que uma das condições fundamentais do "trânsito necessário para a abolição das diferenças de classe" é a expropriação da burguesia.

Diante disto, podemos afirmar que Marx nunca conceituou a Comuna de Paris como ditadura do proletariado, e Engels o fez apenas circunstancialmente, porque apesar da ruptura e da criação que realizou em termos políticos, quebrando a maquinaria do Estado burguês, ela pouco avançou em termos econômico-sociais. Em outras palavras, apesar de a Comuna ter promovido uma radical socialização política, abolindo a distinção entre governantes e governados, ter se transformado na "forma política, finalmente descoberta, com a qual se realiza a emancipação econômica do trabalho" (segundo a definição do próprio Marx), ela pouco avançou nesse último quesito. Não houve tempo para levar a cabo a expropriação dos capitalistas pelos trabalhadores, não houve tempo para a "socialização dos meios de produção".

A medida da Comuna que mais avançou nessa direção, e ainda assim pouco efetivada, foi o confisco das fábricas fechadas, ou abandonadas pelos proprietários que fugiram de Paris, e sua entrega às cooperativas de trabalhadores em uma situação de emergência ditada pela necessidade de 
sustentar materialmente a revolução. Não houve tempo para mais nada em termos econômico-sociais, com exceção de medidas como a moratória das dívidas e aluguéis, a criação de direitos trabalhistas e a democratização da educação.

Isso indica que Marx entendia o conceito de ditadura do proletariado de modo integral, não politicista; não só como um processo de ruptura política que quebrasse o Estado burguês e instituísse a democracia direta, mas como uma revolução social que desencadeasse a abolição das classes e todas as suas consequências sociais e ideológicas, por meio da expropriação do capital, do fim da separação entre capital e força de trabalho. Apesar de dar início a esse processo, a Comuna não avançou muito em sua concretização, o que não implica dizer que ela não apresentasse na prática uma possibilidade que até então era apenas prevista teoricamente, e nem que não tenha sido um marco político e teórico na luta revolucionária. Como o próprio Marx afirma, na resolução da AIT que celebrou o primeiro aniversário da Comuna, ela foi "a aurora da revolução social que libertará para sempre a humanidade do regime das classes" (MARX, 1983, p. 311). Apesar de apenas dar o primeiro passo na transição anunciada por Marx, a Comuna de Paris esteve muito mais próxima da ditadura do proletariado do que muitas das experiências assim autodenominadas, que, no entanto, ficaram bastante aquém do que ela realizou no curto tempo de sua existência.

\section{Marx and the Paris Commune}

Abstract: Since 1871, the discussion about the Commune of Paris has involved not only historians and social scientists, but militants and politic leaderships from several positions. For Marxists, the Commune of Paris is considered a historic mark on the anticapitalist fight, identified as the first specific proletariat revolution of History, which inspired others revolutionary movements. It was positively associated with the concept of proletariat dictatorship, as its first historic demonstration. In this work we intend to present an alternative reading of the Commune, taking by basis Marx own formulations, to whom this was only a first step toward proletariat dictatorship, without, however, built itself as one, since it had been aborted by the counter-revolutionary violence, preventing it to carry out the expropiation from the capitalists by the workers.

KEY WORDS: Commune of Paris, proletariat dictatorship, social revolution.

\section{NOTAS}

1 Essas informações aparecem na edição francesa de A Guerra Civil na França. Ver Marx, 1972. 
2 Vejam as cartas a W. Liebknecht, de 6 de abril, e a L. Kugelman, de 12 e 17 de abril de1871 (MARx, 2011, p. 207-209), em que Marx levanta algumas das críticas à Comuna que são apresentadas em A Guerra Civil na França e, ao mesmo tempo, reconhece sua importância histórica e seu caráter proletário.

3 Na "Introdução" à edição de 1891 de A Guerra Civil na França, Engels ainda levanta o erro da Comuna em não confiscar o Banco da França, que pagava o soldo das tropas governistas que atacavam Paris, e assim asfixiar o governo Thiers e forçar a burguesia francesa a negociar com os communards (ENGELs, 2011, p. 194).

\section{REFERÊNCIAS}

Engels, F. Introdução à Guerra Civil na França, de Karl Marx. In: Marx, K. A Guerra Civil na França. São Paulo: Boitempo, 2011. p. 187-197.

Mclellan, D. Karl Marx: vida e pensamento. Petrópolis, RJ: Vozes, 1990.

Marx, K.; Engels, F. Manifesto do Partido Comunista. Obras escolhidas. Lisboa: Avante, 1982a. p. 95-136. v. I.

Marx, K. As lutas de classes em França de 1848 a 1850. In: Marx, K.; Engels, F. Obras escolhidas. Lisboa: Avante, 1982b. p. 209-309. v. I.

MARX, K. Resoluções tomadas na reunião para celebrar o aniversário da Comuna. In: MARX, K.; Engels, F. Obras escolhidas. Lisboa: Avante, 1983. p. 311-312. v. II

Marx, K.; Engels, F. Anotações ao livro Estatismo e anarquia de Bakunin (extrato). Margem esquerda, São Paulo: Boitempo, 2003. p. 149-155. n. 1.

Marx, K.; Engels, F. Marx a Wilhelm Liebknecht, de 6 de abril de 1871. A Guerra Civil na França. São Paulo: Boitempo, 2011. p. 207.

Marx, K.; Engels, F. Marx a Ludwig Kugelman, de 12 de abril de 1871. A Guerra Civil na França. São Paulo: Boitempo, 2011. p. 207-208.

Marx, K.; Engels, F. Marx a Ludwig Kugelman, de 17 de abril de 1871. A Guerra Civil na França. São Paulo: Boitempo, 2011. p. 209.

Marx, K.; Engels, F. Crítica ao Programa de Gotha. Obras escolhidas, São Paulo: Alfa-Ômega, s.d., p. 209-225. v. 2.

Marx, K.; Engels, F. A Guerra Civil na França. São Paulo: Boitempo, 2011.

Rougerie, J. Tradição e criação na Comuna de Paris. Crítica Marxista, São Paulo: Boitempo, 2001. p. 122-147.

TEXIER, J. Revolução e democracia em Marx e Engels. Rio de Janeiro: Ed. UFRJ, 2005. 